\title{
Remembering Pioneers in Patient Treatments
}

\section{David A Prentice*}

Catholic University of America, Family Research Council, Washington, USA

It was very heartening to see Dr. Shinya Yamanaka recognized with the 2012 Nobel Prize for Physiology or Medicine [1], for his work in development of induced pluripotent stem cells (iPS cells), an ethical route to create pluripotent stem cells [2]. Even more heartening was Dr. Yamanaka's rationale for creation of iPS cells, and his ultimate aim, the patients:

"So my goal, all my life is to bring this technology, stem cell technology to the bedside, to patients, to clinics" [3].

We sometimes lose sight of that ultimate goal, the real reason behind our exciting laboratory investigations, late nights in the lab, grant submissions, published papers, and talks at meetings. That is why it is so important to celebrate these pioneers of basic science and of patient treatments. It is also important to remember practitioners who have labored in the laboratory and in the clinic, with that patientcentered goal in mind.

The last couple of years have seen the passing of several patientcentered pioneers in the field of regenerative medicine. Perhaps, most noticed was the death in January 2011 of Canadian scientist Ernest McCulloch. The late Dr. McCulloch and his colleague James Till were pioneers in bone marrow transplant and bone marrow adult stem cells. Their early work with mice in the 1960's provided the first evidence for the existence of bone marrow adult stem cells [4], and laid the theoretical groundwork for applications in bone marrow and adult stem cell transplantation [5].

Another early pioneer whose passing went relatively unnoticed at the time was French scientist Dr. Georges Mathe, who died in October 2010 [6]. In 1958, he used donor bone marrow transplants to save several physicists, accidentally exposed to high doses of radiation [7], and published one of the first successful donor bone marrow transplants for a patient with acute lymphoblastic leukemia, in 1963 [8].

In 2012, we lost two more pioneers who were dedicated to pushing the frontiers of patient treatment using adult stem cells. The passing of these two patient-centered pioneers should not go unnoticed, nor should they and their accomplishments be forgotten.

Dr. Julio Voltarelli of Brazil died in March of 2012. Dr. Voltarelli was a Professor at the Ribeirão Preto School of Medicine at the University of São Paulo, Brazil. He developed a highly ranked bone marrow and stem cell transplantation program, and initiated research efforts for adult stem cell transplants directed at autoimmune diseases, including Type I diabetes. The efforts bore fruit, resulting in at least 20 Type I diabetes patients becoming insulin free, after their treatment. The first, groundbreaking results were published in 2007 [9]. The research team published a follow-up paper in 2009 that included additional patients, noting that at that time, their technique utilizing the patient's own adult stem cells was "the only treatment capable of reversing type 1 DM in humans" [10].

Dr. Carlos Lima of Portugal passed unexpectedly in June, 2012. Dr. Lima was a pioneer in the use of nasal mucosal tissue containing adult stem cells for the treatment of spinal cord injury. He built a skilled team at the Hospital de Egas Moniz in Lisbon, Portugal, and included international collaborators to bring the best neurological expertise, to bear on the problem of using regenerative medicine techniques for treatment of spinal cord injuries. The team's first publication in 2006 provided information on the first few patients to undergo the technique and experience clinical improvement [11]. Their 2010 paper showed more extensive data, with significant improvement in paraplegic and quadriplegic spinal cord injury patients, even when treatment was begun years after the injury. They observed that 12 of 13 AIS A patients improved in AIS grade, and all of the patients regained some muscle movement in their legs [12].

As we celebrate the accomplishments of these pioneers, let us remember them and their goal-to keep the focus on the patients.

\section{References}

1. Gurdon JB, Yamanaka S (2012) The Nobel Prize in Physiology or Medicine Press Release. Nobelprize.org.

2. Takahashi K, Yamanaka S (2006) Induction of pluripotent stem cells from mouse embryonic and adult fibroblast cultures by defined factors. Cell 126 663-676.

3. Shinya Yamanaka - Interview (2012) Nobelprize.org

4. Siminovitch L, Mcculloch EA, Till JE (1963)The distribution of colony-forming cells among spleen colonies. J Cell Physiol 62: 327-336.

5. Becker AJ, Mcculloch EA, Till Je (1963) Cytological demonstration of the clonal nature of spleen colonies derived from transplanted mouse marrow cells. Nature 197: 452-454.

6. Martin D (2010) Dr. Georges Mathé, Transplant Pioneer, Dies at 88

7. Mathe G, Jammet H, Pendic B, Schwarzenberg L, Duplan JF, et al. (1959) Transfusions and grafts of homologous bone marrow in humans after accidental high dosage irradiation. Rev Fr Etud Clin Biol 4: 226-238.

8. Mathe G, Amiel JL, Schwarzenberg L, Cattan A Schneider M (1963) Haematopoietic Chimera in Man after Allogenic (Homologous) Bone-Marrow Transplantation. (Control Of The Secondary Syndrome. Specific Tolerance Due To The Chimerism). Br Med J 2: 1633-1635.

9. Voltarelli JC, Couri CEB, Stracieri ABPL, Oliveira MC, Moraes DA, et al. (2007) Autologous nonmyeloablative hematopoietic stem cell transplantation in newly diagnosed Type 1 Diabetes Mellitus. JAMA 297: 1568-1576.

10. Couri CEB, Oliveira MCB, Stracieri ABPL, Moraes DA, Pieroni $F$, et al (2009) C-peptide levels and insulin independence following autologous nonmyeloablative hematopoietic stem cell transplantation in newly diagnosed type 1 diabetes mellitus. JAMA 301: 1573-1579.

11. Lima C, Pratas-Vital J, Escada P, Hasse-Ferreira A, Capucho C, et al. (2006) Olfactory mucosa autografts in human spinal cord injury: a pilot clinical study. $J$ Spinal Cord Med 29: 191-203.

12. Lima C, Escada P, Pratas-Vital J, Branco C, Arcangeli CA, et al. (2010) Olfactory mucosal autografts and rehabilitation for chronic traumatic spinal cord injury. Neurorehabil Neural Repair 24: 10-22.

${ }^{*}$ Corresponding author: David A Prentice, Adjunct Professor, Catholic University of America, Senior Fellow Family Research Council, Washington, USA, Tel: 202-637-4616; Fax: 202-393-2134; E-mail: dap@FRC.ORG

Received October 19, 2012; Accepted October 22, 2012; Published October 24 2012

Citation: Prentice DA (2012) Remembering Pioneers in Patient Treatments. J Tissue Sci Eng 3:e119. doi:10.4172/2157-7552.1000e119

Copyright: (c) 2012 Prentice DA. This is an open-access article distributed under the terms of the Creative Commons Attribution License, which permits unrestricted use, distribution, and reproduction in any medium, provided the original author and source are credited. 